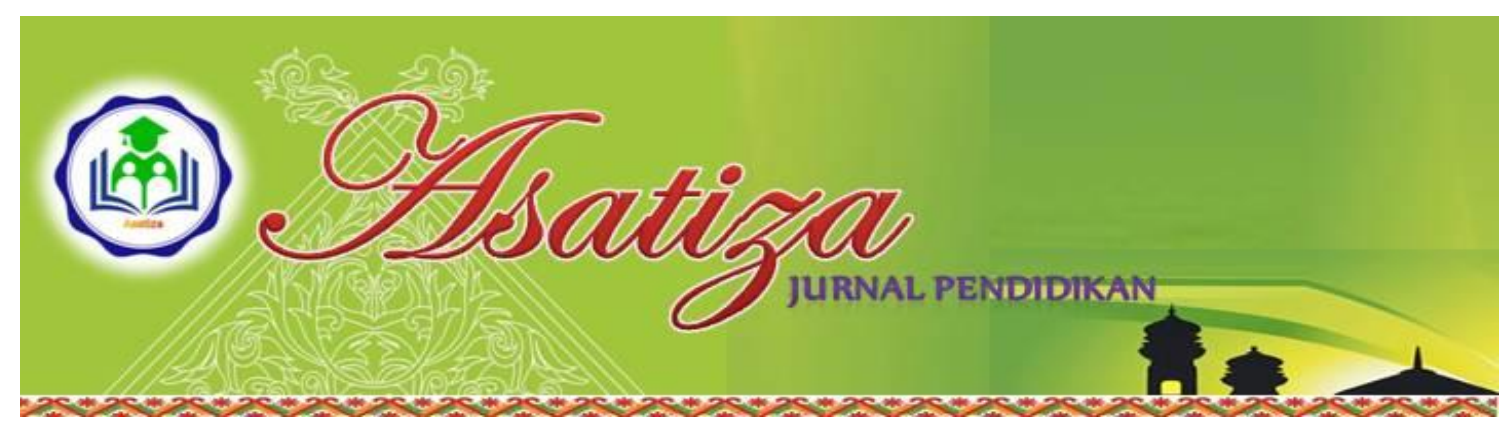

\title{
PENGARUH INTERAKSI EDUKATIF GURU TERHADAP MOTIVASI BELAJAR SISWA PADA MATA PELAJARAN PENDIDIKAN AGAMA ISLAM DI SEKOLAH MENENGAH KEJURUAN NEGERI 2 TEMBILAHAN
}

\author{
Puspita Dwi Handayani ${ }^{1}$ \\ ${ }^{1}$ STAI Auliaurrasyidin Tembilahan
}

\section{Abstrak}

Tujuan penelitian untuk mengetahui apakah ada pengaruh interaksi edukatif guru terhadap motivasi belajar siswa pada mata pelajaran Pendidikan Agama Islam di SMKN 2 Tembilahan.

Jenis penelitian ini adalah penelitian deskriptif kuantitatif. Populasi dalam penelitian ini yaitu 25 orang siswa kelas XI jurusan TKJ di SMKN 2 Tembilahan. Sampel dalam penelitian ini adalah nonprobability sampling menggunakan sampling jenuh. Teknik pengumpulan data yang penulis gunakan adalah angket dan dokumentasi. Teknik analisa data yang digunakan adalah teknik analisa data rumus regresi sederhana.

Berdasarkan hasil penelitian yang telah penulis lakukan di SMKN 2 Tembilahan dapat disimpulkan bahwa interaksi edukatif guru di SMKN 2 Tembilahan berada pada kategori sedang yakni $62 \%$ sedangkan motivasi belajar siswa berada pada kategori sedang yakni $52 \%$, selain itu terdapat pengaruh yang signifikan antara interaksi edukatif guru terhadap motivasi belajar siswa pada mata pelajaran Pendidikan Agama Islam di SMKN 2 Tembilahan berdasarkan hipotesis $\mathrm{H}_{\mathrm{a}}$ terima dan $\mathrm{H}_{0}$ ditolak dengan ketentuan hipotesis $\mathrm{F}_{\text {hitung }} 60,9>\mathrm{F}_{\text {tabel }} 4,28$.

Kata Kunci: Interaksi Edukatif, Motivasi Belajar

\section{A. PENDAHULUAN}

\section{Latar belakang}

Pendidikan merupakan segala situasi hidup pertumbuhan individu sebagai pengalaman belajar yang berlangsung dalam segala lingkungan dan sepanjang hidup serta pendidikan dapat diartikan sebagai pengajaran yang diselenggarakan di sekolah sebagai pendidikan formal. ${ }^{1}$

Proses belajar mengajar akan senantisa merupakan proses interaksi

${ }^{1}$ Syaiful Sagala, Konsep dan Pembelajaran, (Bandung, Alfabeta, 2006), hlm. 1 antara dua unsur manusiawi, yakni siswa sebagai pihak yang belajar dan guru sebagai pihak yang mengajar, dengan siswa sebagai subjek pokoknya. Dari berbagai bentuk interaksi, khususnya mengenai interaksi yang disengaja, ada istilah interaksi edukatif.

Interaksi edukatif adalah interaksi yang berlangsung dalam suatu ikatan untuk tujuan pendidikan dan pengajaran. Dalam arti yang lebih spesifik pada bidang pengajaran dikenal adanya istilah interaksi belajarmengajar. Dengan kata lain, apa yang 
dinamakan interaksi edukatif, secara khusus adalah sebagai interaksi belajarmengajar. Interaksi belajar-mengajar mengandung suatu arti adanya kegiatan interaksi dari tenaga pengajar yang melaksanakan tugas mengajar di satu pihak, dengan warga belajar (siswa, anak didik/subjek belajar) yang sedang melaksanakan kegiatan belajar di pihak lain. $^{2}$

Menurut Syaiful Bahri Djamrah, interaksi edukatif adalah hubungan dua arah antara guru dan anak didik dengan sejumlah norma sebagai mediumnya untuk mencapai tujuan pendidikan. ${ }^{3}$ Dalam interaksi edukatif unsur guru dan anak didik harus aktif, tidak mungkin terjadi proses interaksi edukatif bila hanya satu unsur yang aktif. Aktif dalam arti sikap, mental dan perbuatan. Selain dari pada itu interaksi edukatif diharapkan merupakan proses motivasi. Maksudnya, bagaimana dalam proses interaksi itu pihak pengajar mampu memberikan dan mengembangkan motivasi kepada pihak warga belajar/siswa/anak didik.

Masalah yang masih terjadi berdasarkan pengamatan penulis, siswa belum sepenuhnya aktif dalam proses pembelajaran, masih ada siswa yang belum mampu menyimpulkan materi yang telah disampaikan oleh gurunya, masih ada siswa yang belum berani mengkomunikasikan apa yang belum mereka pahami terkait materi yang

${ }^{2}$ Sardiman A.M., Interaksi dan Motivasi Belajar Mengajar, (Jakarta, Rajawali Press, 2016), hlm. 1

${ }^{3}$ Syaiful Bahri Djamrah, Guru dan Anak Didik dalam Interaksi Edukatif, (Jakarta, Rineka Cipta, 2000), hlm. 10 telah diajarkan. Sehingga hal ini menyebabkan komunikasi dalam pembelajaran hanya terjadi satu arah yakni dari guru ke siswa. Padahal seharusnya pembelajaran dalam Kurikulum 2013 terjadi interaksi antara guru dengan siswa, siswa dengan guru dan siswa dengan siswa lainnya sehingga terjadi hubungan timbal balik dalam proses pembelajaran.

Selain itu, masih adanya siswa yang kurang memperhatikan penjelasan guru dengan baik dan sibuk sendiri, menurut penulis disebabkan oleh masih kurang optimalnya pelaksanaan komponen interaksi edukatif dalam proses pembelajaran.

Agar memperoleh hasil yang optimal, proses belajar mengajar harus dilakukan dengan sadar dan sengaja serta terorganisasi secara baik. Namun, tidak semua tujuan diadakannya proses pembelajaran dapat diperoleh semudah membalikkan telapak tangan. Seringkali kita temui berbagai faktor penghambat tercapainya tujuan pembelajaran tersebut. Salah satunya adalah rendahnya motivasi dalam belajar. Untuk dapat belajar dengan baik diperlukan proses dan motivasi belajar yang baik pula.

Menurut Abdul Hadis dan Nurhayati, motivasi belajar ialah daya penggerak yang timbul dari dalam individu atau siswa yang mendorong individu melakukan aktivitas belajar. ${ }^{4}$

Selaras dengan pendapat yang diutarakan sebelumnya, menurut Hamzah B Uno yang dikutip oleh Mohamad Syarif Sumantri dalam

${ }^{4}$ Abdul Hadis, Nurhayati, Psikologi dalam Pendidikan, (Bandung, Alfabeta, 2014), hlm. 30 
bukunya Strategi Pembelajaran menyatakan bahwa:

Motivasi belajar adalah dorongan dan kekuatan dalam diri seseorang untuk melakukan tujuan tertentu yang ingin dicapainya. Dengan kata lain motivasi belajar dapat diartikan sebagai suatu dorongan yang ada pada diri seseorang sehingga seseorang mau melakukan aktivitas atau kegiatan belajar guna mendapatkan beberapa keterampilan dan pengalaman. ${ }^{5}$

Berdasarkan hasil observasi dan wawancara awal dengan guru mata pelajaran Pendidikan Agama Islam di SMKN 2 Tembilahan masih dijumpai siswa yang kurang semangat belajar di dalam kelas, masih ada siswa yang malas mengerjakan tugas, masih ada siswa yang tidak memiliki keinginan untuk mengetahui, dan masih ada siswa yang mendapat nilai buruk. Berdasarkan masalah tersebut penulis tertarik untuk melakukan penelitian dengan mengambil judul "Pengaruh interaksi edukatif guru terhadap motivasi belajar siswa pada mata pelajaran pendidikan agama Islam (PAI) di SMKN 2Tembilahan

\section{Pengertian Interaksi Edukatif}

Menurut sardiman A.M, interaksi edukatif adalah interaksi yang berlangsung dalam suatu ikatan untuk tujuan pendidikan dan pengajaran. Dalam arti yang lebih spesifik pada bidang pengajaran, dikenal adanya istilah interaksi

${ }^{5}$ Mohamad Syarif Sumantri, Strategi Pembelajaran: Teori dan Praktik di Tingkat Pendidikan Dasar, (Jakarta, Rajawali Press, 2015), hlm. 378 belajar-mengajar. Dengan kata lain, apa yang dinamakan interaksi edukatif, secara khusus adalah sebagai interaksi belajar-mengajar. ${ }^{6}$

Selaras dengan pendapat itu, menurut Zainal Aqib dan Elham Rahmanto, interaksi belajarmengajar adalah suatu kegiatan yang bersifat interaktif dari berbagai komponen untuk mewujudkan tercapainya tujuan pembelajaran yang telah ditetapkan dalam perencanaan pembelajaran. ${ }^{7}$

Menurut Syaiful Bahri Djamrah, interaksi edukatif adalah hubungan dua arah antara guru dan anak didik dengan sejumlah norma sebagai mediumnya untuk mencapai tujuan pendidikan. ${ }^{8}$

Berdasarkan pengertian di atas dapat disimpulkan bahwa interaksi edukatif adalah hubungan timbalbalik antara guru dan siswa dengan sejumlah komponen-komponen guna mencapai tujuan pembelajaran seperti yang diharapkan.

\section{Pengertian Motivasi Belajar}

Setiap aktivitas manusia pada dasarnya dilandasi oleh adanya dorongan untuk mencapai tujuan atau terpenuhinya kebutuhannya.

6 Sardiman A.M. Interaksi dan Motivasi Belajar Mengajar (Jakarta, RajaGrafindo Persada, 2007), hlm. 1

${ }^{7}$ Zainal Aqib, Elham Rahmanto, Membangun Profesionalisme Guru dan Pengawas Sekolah, (Bandung, Yrama Widya, 2007), hlm. 58

${ }^{8}$ Syaiful Bahri Djamarah, Guru dan Anak Didik dalam Interaksi Edukatif, (Jakarta, Rineka Cipta, 2000), hlm. 11 
Adanya daya pendorong ini disebut motivasi. ${ }^{9}$

Banyak para ahli khususnya dalam dalam bidang psikologi yang berusaha untuk mengungkap tentang motivasi.

Selaras dengan pendapat di atas, menurut Rohmanlina Wahab motivasi adalah keseluruhan dorongan, keinginan, kebutuhan, dan daya yang sejenis yang menggerakkan perilaku seseorang. Dalam arti lebih luas, motivasi diartikan sebagai pengaruh dari energi dan arahan terhadap perilaku yang meliputi: kebutuhan, minat, sikap, keinginan dan perangsang. ${ }^{10}$

Sedangkan motivasi belajar menurut Abdul Hadis dan Nurhayati adalah daya penggerak yang timbul dari dalam diri individu atau siswa yang mendorong individu melakukan aktivitas belajar. motivasi belajar juga dapat didefinisikan sebagai kekuatan yang timbul dari dalam diri individu yang mendorong individu melakukan aktivitas belajar. $^{11}$

Sesuai dengan pendapat di atas, menurut Hamzah Uno yang telah dikutip oleh Mohamad Syarif Sumantri bahwa:

"Motivasi belajar adalah dorongan dan kekuatan dalam

\footnotetext{
${ }^{9}$ Nyanyu Khodijah, Psikologi Pendidikan, (Jakarta, Rajawali Press, 2016), hlm. 149

${ }^{10}$ Rohmalina wahab, Psikologi belajar, (Jakarta, Rajawali Press, 2016), hlm. 127

${ }^{11}$ Abdul Hadis dan Nurhayati, Psikologi dalam Pendidikan, (Bandung, Alfabeta, 2014), hlm. 30
}

diri seseorang untuk melakukan tujuan tertentu yang ingin dicapainya. Dengan kata lain motivasi belajar dapat diartikan sebagai suatu dorongan yang ada pada diri seseorang sehingga seseorang mau melakukan aktivitas atau kegiatan belajar guna mendapatkan beberapa keterampilan pengalaman." 12

Selain itu Ahim Surachim juga berpendapat bahwa motivasi belajar adalah kekuatan yang diperlukan peserta didik untuk meraih suatu prestasi, bekal berharga untuk meraih prestasi belajar terbaik. $^{13}$

Hakikat motivasi belajar adalah dorongan internal dan eksternal pada siswa-siswa yang sedang belajar untuk mengadakan perubahan tingkah laku, pada umumnya dengan beberapa indikator atau unsur yang mendukung. Hal itu mempunyai peranan besar dalam keberhasilan seseorang dalam belajar. indikator motivasi belajar dapat diklasifikasikan sebagai berikut:

a. Adanya hasrat dan keinginan berhasil

b. Adanya dorongan dan kebutuhan dalam belajar

c. Adanya harapan dan cita-cita masa-depan

${ }^{12}$ Mohamad Syarif Sumantri, Strategi Pembelajaran: Teori dan Praktik di Tingkat Pendidikan Dasar, (Jakarta, Rajawali Press, 2015), hlm. 378

${ }^{13}$ Ahim surachim, Efektivitas Pembelajaran: Pola Pendidikan Sistem Ganda, (Bandung, Alfabeta, 2016), hlm. 79 
d. Adanya penghargaan dalam belajar

e. Adanya kegiatan yang menarik dalam belajar

f. Adanya lingkungan belajar yang kondusif, sehingga memungkinkan seseorang siswa dapat belajar dengan baik. $^{14}$

Dari beberapa pendapat diatas penulis menyimpulkan bahwa motivasi belajar adalah kekuatan yang terdapat dalam diri seorang individu yang mendorongnya untuk melakukan suatu aktivitas belajar untuk mendapatkan tujuan yang ingin dicapainya. Yakni tujuan belajar berupa keterampilan dan pengalaman.

\section{B. METODOLOGI}

Jenis penelitian yang digunakan dalam penelitian ini adalah penelitian kuantitatif. Dengan menggunakan pendekatan Ex-Post Facto. Menurut Kerlinger dalam buku Sukardi Ex-Post Facto merupakan penelitian dimana variabel-variabel bebas telah terjadi ketika peneliti mulai dengan pengamatan variabel terikat dalam suatu penelitian. pada penelitian ini, keterikatan antar variabel bebas dengan variabel bebas, maupun antar variabel bebas dengan variabel terikat sudah terjadi secara alami, dan peneliti dengan setting tersebut ingin melacak kembali jika memungkinkan apa yang menjadi Penelitian deskriptif ini juga

${ }^{14}$ Hamzah B. Uno, Teori Motivasi dan Pengukurannya, (Jakarta, Bumi Aksara, 2017), hlm. 23 disebut penelitian faktor penyebabnya. $^{15}$

Penelitian kuantitatif dapat diartikan sebagai metode penelitian yang berlandasakan pada filsafat positivisme, digunakan untuk meneliti pada populasi atau sampel tertentu, pengumpulan data menggunakan instrumen penelitian, analisis data bersifat kuantitatif/ sttistik, dengan tujuan untuk menguji hipotesis yang telah ditetapkan. ${ }^{16}$

Subjek penelitian adalah siswa kelas XI jurusan TKJ Sekolah Menengah Kejuruan Negeri 2 Tembilahan. Sedangkan objek dalam penelitian ini adalah pengaruh interaksi edukatif guru terhadap motivasi belajar siswa pada mata pelajaran Pendidikan Agama Islam di Sekolah Menengah Kejuruan Negeri 2 Tembilahan

Populasi dalam penelitian ini adalah siswa kelas XI jurusan TKJ berjumlah 25 orang. E. Teknik

Pengumpulan Data angket dan dokumentasi. Teknik analisa data merupakan cara menganalisis data penelitian, termasuk alat-alat statistikyang relevan untuk digunakan dalam penelitian. ${ }^{17}$

Teknik analisis variabel $\mathrm{X}$ dan $\mathrm{Y}$. Penelitian ini memiliki dua variabel yaitu variabel bebas $(\mathrm{X})$ atau interaksi edukatif guru dan variabel terikat $(\mathrm{Y})$

${ }^{15}$ Sukardi, Metodologi Penelitian Pendidikan: Kompetensi dan Praktiknya, (Jakarta, Bumi Aksara), hlm. 165

${ }^{16}$ Sugiyono, Metode Penelitian: Kuantitatif, Kualitatif, dan $R \& D$, (Bandung, Alfabeta,2015), hlm. 8

${ }^{17}$ Juliansyah Noor, Metodologi Penelitian:

Skripsi, Tesis, Disertasi, dan Karya Ilmiah,

(Jakarta, Kencana Prenada Media Group, 2012), hlm. 163 
atau motivasi belajar. Dalam penelitian ini teknik pengumpulan data kedua variabel menggunakan angket. Sehingga untuk menganalisis kedua variabel tersebut menggunakan mengunakan mean (M) dan standar deviasi (SD). Mean merupakan ratarata hitung dan standar deviasi (simpangan baku) adalah kelompok atau ukuran standar penyimpangan dari reratanya. Dalam menyusun distribusi frekuensi, digunakan langkah langkah sebagai berikut:

Menentukan jumlah kelas interval. Rumus untuk menentukan jumlah kelas interval yaitu menggunakan rumus Sturges yakni jumlah kelas interval $=1+3,3 \log n$. Dimana $n$ adalah jumlah responden.

a. Menentukan rentang data (Range)

Rentang kelas $=$ skor maksimum skor minimum +1

b. Menentukan panjang kelas interval Panjang kelas interval = Rentang data

Jumlah kelas interval

Data variabel penelitian perlu dikategorikan dengan langkah langkah sebagai berikut:

a. Kelompok tinggi, semua responden yang mempunyai skor rata-rata plus $1 \quad(+1)$ standar deviasi ( $\mathrm{X} \geq \mathrm{Mi}+1 \mathrm{SDi})$

b. Kelompok sedang, semua responden yang mempunyai skor antara skor rata-rata minus 1 standar deviasi dan skor rata-rata plus 1 standar deviasi (antara Mi$1 \mathrm{SDi}) \leq \mathrm{X}<(\mathrm{Mi}+\mathrm{SDi})$

c. Kelompok kurang, semua responden yang mempunyai skor lebih rendah dari skor rata-rata minus 1 standar deviasi $(\mathrm{X}<\mathrm{Mi}-$ SDi)

Sedangkan harga mean ideal (Mi) dan Standar Deviasi ideal (SDi) diperoleh berdasarkan rumus berikut:

Mean ideal $(\mathrm{Mi})=1 / 2$ (skor tertinggi + skor terendah)

Standar deviasi ideal $=1 / 6$ ( skor tertinggi - skor terendah)

Teknik analisis hipotesis

Data yang sudah terkumpul, dituangkan dalam bentuk angka-angka. Sehingga data tersebut bersifat kuantitatif. Pengalihan data ke dalam bentuk kuantitatif ini ditempuh dengan menggunakan rumus analisa regresi sederhana, yaitu: ${ }^{18}$

Persamaan regresi sederhana dirumuskan: $\hat{Y}=\alpha+b X$

Dimana:

$\hat{\mathrm{Y}} \quad=$ (baca $\mathrm{Y}$ topi) subjek variabel terikat yang diproyeksikan

$\mathrm{X}=$ variabel bebas yang mempunyai nilai tertentu untuk diprediksikan

$=$ nilai konstanta harga $\mathrm{Y}$ jika $\mathrm{X}=0$

$\mathrm{b}=$ nilai arah sebagai penentu ramalan (prediksi) yang menunjukkan nilai peningkatan (+) atau nilai penurunan (-) variabel Y

langkah-langkah menjawab regresi sederhana:

langkah 1 membuat $\mathrm{H}_{0}$ dan $\mathrm{H}_{0}$ dalam bentuk kalimat

langkah 2 membuat $\mathrm{H}_{0}$ dan $\mathrm{H}_{0}$ dalam bentuk statistik

${ }^{18}$ Ridwan, Metode dan Teknik Menyusun Tesis, (Bandung, Alfabeta, 2001), hlm. 145-146 
langkah 3 membuat tabel penolong untuk menghitung angka statistik.

Langkah 4 masukkan angkaangka dari tabel penolong dengan rumus:

$\mathrm{b}=\frac{\sum X \cdot Y-\sum X \cdot \sum Y}{\mathrm{n} \cdot \sum \mathrm{X}^{2}-\left(\sum \mathrm{X}\right)^{2}}$
$\frac{\mathrm{a}=\sum \mathrm{Y}-\mathrm{b} \cdot \sum \mathrm{X}}{\mathrm{n}}$

Langkah 5 mencari jumlah kuadrat regresi (JKReg[a]) dengan rumus:

$J_{\mathrm{Reg}[\mathrm{a}]}=\frac{(\mathrm{XY})^{2}}{\mathrm{~N}}$

Langkah 6 mencari jumlah kuadrat regresi (JKReg[a]) dengan

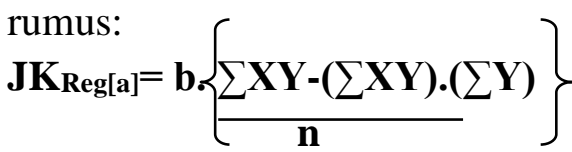

Langkah 7 mencari jumlah kuadrat residu (JKRes) dengan rumus:

$J_{\text {Res }}=\sum Y 2-J_{\text {Reg(b)(a) }}$ -

JKReg(a)

Langkah 8 mencari rata-rata jumlah kuadrat regresi

(RJK $\left.\mathrm{Reg}_{\mathrm{R}]}\right)$ dengan rumus:

$\mathbf{R J K}_{\operatorname{Reg}[\mathrm{a}]}=\mathbf{J K}_{\mathbf{R e g}[\mathrm{a}]}$

Langkah 9 mencari rata-rata jumlah kuadrat regresi

$\left(\mathrm{RJK}_{\operatorname{Reg}(\mathrm{b} \mid \mathrm{a})}\right)$ dengan rumus:

$\mathbf{R J K}_{\operatorname{Reg}(\mathbf{b} \mid \mathbf{a})=}=\mathbf{J K}_{\operatorname{Reg}[\mathbf{b} \mid \mathbf{a}]}$

Langkah 10 mencari rata-rata jumlah kuadrat residu

$\mathrm{RJK}_{\text {Res }}$ dengan rumus:

$\mathbf{R J K}_{\mathrm{Res}}=\frac{\mathbf{J K}_{\mathrm{Res}}}{\mathbf{n}-\mathbf{2}}$

Langkah 11 menguji signifikan dengan rumus:

$\mathbf{F}_{\text {Hitung }}=\mathbf{R J K}_{\text {Res }(\mathbf{b} \mid \mathbf{a})}$ RJK Res
Kaidah pengujian signifikasi:

Jika $F_{\text {hitung }} \geq \mathrm{F}_{\text {tabel }}$, maka tolak $\mathrm{H}_{0}$ artinya signifikan dan

Jika $F_{\text {hitung }} \leq \mathrm{F}_{\text {tabel, }}$ terima $\mathrm{H}_{0}$ artinya tidak signifikan.

Selain cara manual diatas, penulis juga menggunakan program SPSS untuk menguji apakah perhitungan manual yang dilakukan valid. Sehingga analisis yang didapat benar-benar telah melalui tahapan pengujian untuk mendapatkan uji hipotesis yang benar.

\section{PEMBAHASAN}

Variabel interaksi edukatif guru (X) diukur melalui angket yaitu terdiri dari 40 butir pertanyaan dengan skala likert yang terdiri dari 5 alternatif jawaban. Dimana skor 5 untuk skor tertinggi dan 1 untuk skor terendah. Dari butir pertanyaan yang ada, diperoleh nilai tertinggi 159 dan nilai terendah 113. Setelah dihitung dengan menggunakan perhitungan Microsoft Excel 2013 diperoleh hasil Mean sebesar 144,16 dan Standar Deviasi sebesar 11,24.

Untuk menentukan jumlah kelas interval digunakan rumus yaitu jumlah kelas $=1+3,3 \log \mathrm{n}$, dimana $\mathrm{n}$ adalah jumlah sampel atau responden. Dari perhitungan diketahui bahwa $n=25$ sehingga diperoleh banyak kelas $1+$ 3,3 $\log 25=5,587$ dibulatkan menjadi 6 kelas interval. Rentang data dihitung dengan rumus nilai maksimal - nilai minimal +1 , sehingga diperoleh rentang data sebesar $159-113+1=47$, sedangkan panjang kelas yaitu rentanng 
dibagi jumlah kelas $(47 / 6=7,833)$ dibulatkan menjadi 8 .

Distribusi frekuensi variabel interaksi edukatif guru dapat dilihat pada tabel berikut:

\section{Distribusi frekuensi variabel interaksi edukatif}

\begin{tabular}{|c|c|c|c|}
\hline No. & Interval & F & \% \\
\hline 1 & $113-120$ & 1 & 4 \\
\hline 2 & $121-128$ & 1 & 4 \\
\hline 3 & $129-136$ & 4 & 16 \\
\hline 4 & $137-144$ & 6 & 24 \\
\hline 5 & $145-152$ & 6 & 24 \\
\hline 6 & $153-160$ & 7 & 28 \\
\hline \multicolumn{2}{|c|}{ Total } & $\mathbf{2 5}$ & $\mathbf{1 0 0}$ \\
\hline
\end{tabular}

Pada tabel tersebut, menunjukkan frekuensi variabel motivasi belajar paling banyak terletak pada interval 153-160 sebanyak 7 siswa (28\%) dan yang paling sedikit pada interval 113120 dan 121-128 sebanyak 1 siswa (4\%).

Penentuan kecenderungan variabel interaksi edukatif guru, setelah nilai minumum (X $\mathrm{min}$ ) dan nilai maksimum (X mak) diketahui, maka selanjutnya mencari rata-rata ideal $(\mathrm{Mi})=1 / 2(\mathrm{X}$ mak $+\mathrm{X}$ min $)$, mencari standar deviasi ideal (SDi) dengan rumus $\mathrm{Sdi}=1 / 6(\mathrm{Xmak}-\mathrm{Xmin})$. Berdasarkan acuan tersebut mean ideal variabel interaksi edukatif guru adalah 136 dan standar deviasi ideal adalah 8 . Dari perhitungan di atas maka dapat dikategorikan dalam 3 kelas sebagai berikut:

$$
\begin{aligned}
& \text { Tinggi }=\mathrm{X} \geq \mathrm{M}+\mathrm{SD} \\
& \text { Sedang }=\mathrm{M}-\mathrm{SD} \leq \mathrm{X}<\mathrm{M}+\mathrm{SD} \\
& \text { Kurang }=\mathrm{X}<\mathrm{M}-\mathrm{SD}
\end{aligned}
$$

\begin{tabular}{|c|c|c|c|c|}
\hline \multirow{2}{*}{ No. } & \multirow{2}{*}{ Skor } & \multicolumn{2}{|c|}{ Frekuensi } & \multirow{2}{*}{ Kategori } \\
\hline & & Frekuensi & $\%$ & \\
\hline 1 & $>144$ & 4 & 16 & Tinggi \\
\hline 2 & $128<X<144$ & 15 & 60 & Sedang \\
\hline 3 & $<128$ & 6 & 24 & Rendah \\
\hline & Total & 25 & 100 & \\
\hline
\end{tabular}

Distribusi kategorisasi variabel interaksi edukatif guru

disimpulkan bahwa interaksi edukatif guru di Sekolah Menengah Kejuruan negeri 2 Tembilahan berada pada kategori sedang yaitu sebanyak 15 siswa (62\%) dari sampel yang berjumlah 25 siswa .

Untuk mengetahui data motivasi belajar digunakan teknik pengumpulan data berupa angket yang berisi sejumlah pertanyaan yang diberikan kepada 25 siswa kelas XI jurusan TKJ. Pengisian angket dengan menggunakan alternatif jawaban sangat setuju diberi skor 5, setuju diberi skor 4, ragu-ragu diberi skor 3, tidak setuju diberi skor 2, dan sangat tidak setuju diberi skor 1 . Jumlah pertanyaan sebanyak 40 item dengan dua bentuk pertanyaan yaitu pertanyaan positif dan negatif. Untuk penyataan negatif skor alternatif jawaban dibalik yaitu alternatif jawaban selalu diberi skor 1, sering diberi skor 2, kadang-kadang diberi skor 3, hampir tidak pernah diberi skor 4, dan tidak pernah diberi skor 5 .

Variabel motivasi belajar (Y) diukur melalui angket yaitu terdiri dari 40 butir pertanyaan dengan skala likert yang terdiri dari 5 alternatif jawaban. Dimana skor 5 untuk skor tertinggi dan 1 untuk skor terendah. Dari butir pertanyaan yang ada, diperoleh nilai tertinggi 183 dan nilai terendah 124. Setelah dihitung dengan menggunakan 
perhitungan Microsoft Excel 2013 diperoleh hasil Mean sebesar 149,76 dan Standar Deviasi sebesar 12,88.

Untuk menentukan jumlah kelas interval digunakan rumus yaitu jumlah kelas $=1+3,3 \log \mathrm{n}$, dimana $\mathrm{n}$ adalah jumlah sampel atau responden. Dari perhitungan diketahui bahwa $\mathrm{n}=25$ sehingga diperoleh banyak kelas $1+$ 3,3 $\log 25=5,587$ dibulatkan menjadi 6 kelas interval. Rentang data dihitung dengan rumus nilai maksimal - nilai minimal +1 , sehingga diperoleh rentang data sebesar $183-124+1=$ 60, sedangkan panjang kelas yaitu rentanng dibagi jumlah kelas $(60 / 6=$ 9,833) dibulatkan menjadi 10.

Distribusi frekuensi variabel motivasi belajar siswa dapat dilihat pada tabel berikut: Untuk mengetahui data hasil angket motivasi belajar tersebut, penulis akan menyajikan dalam bentuk tabel sebagai berikut:

\section{Distribusi frekuensi variabel motivasi belajar}

\begin{tabular}{|c|c|c|c|}
\hline No. & Interval & F & \% \\
\hline 1 & $124-133$ & 2 & 8 \\
\hline 2 & $134-143$ & 5 & 20 \\
\hline 3 & $144-153$ & 9 & 36 \\
\hline 4 & $154-163$ & 6 & 24 \\
\hline 5 & $164-173$ & 2 & 8 \\
\hline 6 & $174-183$ & 1 & 4 \\
\hline \multicolumn{2}{|c|}{ Total } & 25 & 100 \\
\hline
\end{tabular}

Pada tabel tersebut, menunjukkan frekuensi variabel motivasi belajar paling banyak terletak pada interval 144-153 sebanyak 9 siswa (36\%) dan yang paling sedikit pada interval 174183 sebanyak 1 siswa (4\%).

Penentuan kecenderungan variabel motivasi belajar siswa, setelah nilai minumum (X $\mathrm{min}$ ) dan nilai maksimum (X mak) diketahui, maka selanjutnya mencari rata-rata ideal $(\mathrm{Mi})=1 / 2(\mathrm{X}$ mak $+\mathrm{X}$ min $)$, mencari standar deviasi ideal (SDi) dengan rumus $\mathrm{Sdi}=1 / 6(\mathrm{Xmak}-\mathrm{Xmin})$. Berdasarkan acuan tersebut mean ideal variabel motivasi belajar siswa adalah 154 dan standar deviasi ideal adalah 10. Dari perhitungan di atas maka dapat dikategorikan dalam 3 kelas sebagai berikut:

Tingg $\mathrm{i}=\mathrm{X} \geq \mathrm{M}+\mathrm{SD}$

Sedang $=\mathrm{M}-\mathrm{SD} \leq \mathrm{X}<\mathrm{M}+\mathrm{SD}$

Kurang $=\mathrm{X}<\mathrm{M}-\mathrm{SD}$

Distribusi kategorisasi variabel motivasi belajar siswa

\begin{tabular}{|c|c|c|c|c|}
\hline \multirow{2}{*}{$\begin{array}{c}\text { No } \\
\text { • }\end{array}$} & \multirow{2}{*}{ Skor } & \multicolumn{2}{|c|}{ Frekuensi } & \multirow{2}{*}{$\begin{array}{c}\text { Katego } \\
\text { ri }\end{array}$} \\
\hline & & $\begin{array}{l}\text { Frek } \\
\text { wensi }\end{array}$ & $\%$ & \\
\hline 1 & $>160$ & 5 & 20 & Tinggi \\
\hline 2 & $\begin{array}{c}144<X<1 \\
60\end{array}$ & 13 & 52 & Sedang \\
\hline 3 & $<144$ & 7 & 28 & Rendah \\
\hline & Total & 25 & 100 & \\
\hline
\end{tabular}
disimpulkan bahwa motivasi belajar siswa di Sekolah Menengah Kejuruan negeri 2 Tembilahan berada pada kategori sedang yaitu sebanyak 13 siswa (52\%) dari sampel yang berjumlah 25 siswa.

Untuk mengetahui adanya pengaruh yang positif dan signifikan antara interaksi edukatif guru terhadap motivasi belajar siswa pada mata pelajaran Pendidikan Agama Islam di Sekolah Menengah Kejuruan Negeri 2 Tembilahan, penulis menggunakan analisis regresi sederhana dengan rumus $\hat{Y}=a+b X$. 
yang akan ditempuh langkahlangkah sebagai berikut:

\section{langkah Pertama :}

Membuat $\mathrm{H}_{\mathrm{a}}$ dan $\mathrm{H}_{0}$ dalam bentuk kalimat, di bawah ini:

$\mathrm{H}_{\mathrm{a}}$ : Terdapat pengaruh yang signifikan interaksi edukatif guru terhadap motivasi belajar siswa pada mata pelajaran Pendidikan Agama Islam di Sekolah Menengah Kejuruan Negeri 2 Tembilahan.

$\mathrm{H}_{0}$ : Tidak terdapat pengaruh yang signifikan interaksi edukatif guru terhadap motivasi belajar siswa pada mata pelajaran Pendidikan Agama Islam di Sekolah Menengah Kejuruan Negeri 2 Tembilahan.

\section{Langkah Kedua:}

Membuat $\mathrm{H}_{\mathrm{a}}$ dan $\mathrm{H}_{0}$ dalam bentuk statistik, yaitu:

$$
\begin{aligned}
& \mathrm{H}_{\mathrm{a}}: \mathrm{r} \neq 0 \\
& \mathrm{H}_{0}: \mathrm{r}=0
\end{aligned}
$$

\section{Langkah Ketiga:}

Membuat tabel penolong untuk menghitung angka statistik:

\begin{tabular}{|c|c|c|c|c|c|}
\hline $\begin{array}{c}\text { RESPO } \\
\text { DEN }\end{array}$ & $\mathrm{X}$ & $\mathrm{Y}$ & $\mathrm{X}^{2}$ & $\mathrm{Y}^{2}$ & $\mathrm{XY}$ \\
\hline $\mathrm{R} 1$ & 155 & 165 & 24025 & 27225 & 25575 \\
\hline R2 & 147 & 149 & 21609 & 22201 & 21903 \\
\hline R3 & 134 & 146 & 17956 & 21316 & 19564 \\
\hline R4 & 138 & 139 & 19044 & 19321 & 19182 \\
\hline R5 & 146 & 159 & 21316 & 25281 & 23214 \\
\hline R6 & 154 & 183 & 23716 & 33489 & 28336 \\
\hline R7 & 136 & 148 & 18496 & 21904 & 20276 \\
\hline R8 & 139 & 152 & 19321 & 23104 & 21128 \\
\hline R9 & 159 & 160 & 25281 & 25600 & 25440 \\
\hline R10 & 150 & 150 & 22500 & 22500 & 22500 \\
\hline R11 & 142 & 143 & 20164 & 20449 & 20306 \\
\hline
\end{tabular}

\begin{tabular}{|c|c|c|c|c|c|} 
R12 & 138 & 142 & 19044 & 20164 & 19596 \\
\hline R13 & 155 & 156 & 24025 & 24336 & 24180 \\
\hline R14 & 144 & 145 & 20736 & 21025 & 20880 \\
\hline R15 & 140 & 145 & 19600 & 21025 & 20300 \\
\hline R16 & 150 & 151 & 22500 & 22801 & 22650 \\
\hline R17 & 125 & 124 & 15625 & 15376 & 15500 \\
\hline R18 & 113 & 124 & 12769 & 15376 & 14012 \\
\hline R19 & 134 & 139 & 17956 & 19321 & 18626 \\
\hline R20 & 136 & 137 & 18496 & 18769 & 18632 \\
\hline R21 & 158 & 160 & 24964 & 25600 & 25280 \\
\hline R22 & 157 & 158 & 24649 & 24964 & 24806 \\
\hline R23 & 148 & 156 & 21904 & 24336 & 23088 \\
\hline R24 & 145 & 146 & 21025 & 21316 & 21170 \\
\hline R25 & 159 & 167 & 25281 & 27889 & 26553 \\
\hline Statistik & $\Sigma X$ & $\Sigma Y$ & $\Sigma X^{2}$ & $\Sigma Y^{2}$ & $\Sigma X Y$ \\
\hline Jumlah & 360 & 374 & 52200 & 56468 & 54239 \\
\hline
\end{tabular}

\section{Langkah Keempat:}

Masukkan angka-angka statistik dari tabel penolong dengan rumus:

1. Menghitung rumus

$$
b=\frac{n \cdot \sum X Y-\sum X \cdot \sum Y}{n \cdot \sum X^{2}-\left(\sum X\right)^{2}}
$$

$b$

$$
\begin{gathered}
=\frac{25 \cdot(542395)-(3602) \cdot(3744)}{25 \cdot(522002)-(3602)^{2}} \\
b=\frac{13559875-1348588}{13050050-12974404} \\
b=\frac{73987}{75646} \\
b=0,9780689
\end{gathered}
$$

2. Menghitung rumus a

$$
\begin{aligned}
& a=\frac{\sum Y-b \cdot \sum X}{n} \\
& a=\frac{3744-0,9780689 \cdot(3602)}{25} \\
& a=\frac{3744-3523,004177}{25} \\
& a=\frac{220,9958226}{25} \\
& a=8,839832906
\end{aligned}
$$

3. Menghitung persamaan regresi sederhana 


$$
\begin{aligned}
& \hat{Y}=a+b X \\
& \hat{Y} \\
& =0,9780689 \\
& +8,839832906 .(X)
\end{aligned}
$$

\section{Langkah Kelima:}

Mencari jumlah kuadrat regresi (JKeg[a] $)$ dengan rumus:

$$
\begin{aligned}
& \mathrm{Jk}_{\mathrm{reg}[\mathrm{a}]}=\frac{\left(\sum Y\right)^{2}}{n} \\
& \mathrm{Jk}_{\text {reg[a] }}=\frac{(3744)^{2}}{25} \\
& \mathrm{Jk}_{\text {reg[a] }}=\frac{14017536}{25} \\
& \mathrm{Jk}_{\text {reg }[\mathrm{a}]}=560701,44
\end{aligned}
$$

\section{Langkah Keenam:}

Mencari jumlah kuadrat regresi $\left(j k_{\text {reg }[b \mid a]}\right)$

$$
\mathrm{Jk}_{\mathrm{reg}[\mathrm{b} \mid \mathrm{a}]}=\mathrm{b}\left\{\sum \mathrm{xy}-\frac{\left(\sum X\right) \cdot\left(\sum Y\right)}{n}\right\}
$$$$
\mathrm{Jk}_{\mathrm{reg}[\mathrm{b} \mid \mathrm{a}]}=0,9780689 .\{542395
$$

$$
\left.-\frac{(3602) \cdot(3744)}{25}\right\}
$$

$\mathrm{JK}_{\mathrm{Reg}[\mathrm{b} \mid \mathrm{a}]}=0,9780689 .\{542395$

$$
\left.-\frac{13485888}{25}\right\}
$$

$$
J_{\mathrm{Reg}[\mathrm{b} \mid \mathrm{a}]}=0,9780689 \cdot\{542395
$$$$
-5394,575348\}
$$

$$
\mathrm{JK}_{\mathrm{Reg}[\mathrm{b} \mid \mathrm{a}]}=0,9780689 .(2959,48)
$$

$\mathrm{JK}_{\mathrm{Reg}[\mathrm{b} \mid \mathrm{a}]}=2894,575348$

\section{Langkah Ketujuh:}

Mencari jumlah kuadrat residu ( $\left.\mathrm{JK}_{\mathrm{Res}}\right)$ dengan rumus:

$\mathrm{JK}_{\mathrm{Res}}=\sum Y^{2}-\mathrm{JK}_{\mathrm{Reg}[\mathrm{b} \mid \mathrm{a}]}-\mathrm{JK}_{\mathrm{Reg}[\mathrm{a}]}$

$\mathrm{JK}_{\mathrm{Res}}=564688-2894,575348$

$$
-560701,44
$$

$\mathrm{JK}_{\text {Res }}=1091,984652$

\section{Langkah Kedelapan:}

Mencari rata-rata jumlah kuadrat regresi $\left(\mathrm{RJK}_{\mathrm{Reg}[\mathrm{a}]}\right)$ dengan rumus:

$$
\begin{aligned}
\mathrm{RJK}_{\mathrm{Reg}[\mathrm{a}]} & =\mathrm{Jk}_{\mathrm{reg}[\mathrm{a}]} \\
\mathrm{RJK}_{\text {reg[a] }} & =560701,44
\end{aligned}
$$

\section{Langkah Kesembilan:}

Mencari rata-rata jumlah kuadrat regresi $\left(\mathrm{RJK}_{\mathrm{Reg}[\mathrm{b} \mid \mathrm{a}]}\right)$ dengan rumus:

$\mathrm{RJK}_{\mathrm{Reg}[\mathrm{b} \mid \mathrm{a}]}=\mathrm{JK}_{\mathrm{Reg}[\mathrm{b} \mid \mathrm{a}]}$

$\mathrm{RJK}_{\mathrm{Reg}[\mathrm{b} \mid \mathrm{a}]}=2894,575348$

\section{Langkah Kesepuluh:}

Mencari rata-rata jumlah kuadrat $\left(\mathrm{RJK}_{\mathrm{Res}}\right)$ dengan rumus:

$$
\begin{aligned}
& \mathrm{RJK}_{\text {Res }}=\frac{J K_{\text {Res }}}{\mathrm{N}-2} \\
& \mathrm{RJK}_{\text {res }}=\frac{1091,984652}{25-2} \\
& \mathrm{Rjk}_{\text {res }}=\frac{1091,984652}{23} \\
& \mathrm{RJK}_{\text {Res }}=47,47759357
\end{aligned}
$$

\section{Langkah Kesebelas:}

Menguji Signifikansi dengan rumus:

$$
\begin{aligned}
& F_{\text {hitung }}=\frac{R J K_{\operatorname{Re} g[b \mid a]}}{R J K_{\operatorname{Res}}} \\
& F_{\text {hitung }}=\frac{2894,575348}{47,47759357} \\
& F_{\text {hitung }}=60,967
\end{aligned}
$$

Kaidah pengujian signifikansi:

Jika $F_{\text {hitung }} \geq F_{\text {tabel }}$ maka tolak $\mathrm{H}_{0}$ artinya signifikan

$\mathrm{F}_{\text {hitung }} \leq \mathrm{F}_{\text {tabel }}$ maka terima $\mathrm{H}_{0}$ artinya tidak signifikan

Dengan taraf signifikan: $(\alpha)=0,05$

Carilah nilai $F_{\text {tabel }}$ menggunakan Tabel F dengan rumus:

Ftabel $=\mathrm{F}$

$$
\begin{aligned}
& \left\{(1-\propto)\left(\mathrm{dk} \operatorname{Reg}\left[\frac{\mathrm{b}}{\mathrm{a}}\right]\right),(\mathrm{dk} \operatorname{Res})\right\} \\
& =\mathrm{F} \\
& 0,05)\left(\mathrm{dk} \operatorname{Reg}\left[\frac{\mathrm{b}}{\mathrm{a}}\right]=1\right),(\mathrm{dk} \operatorname{Res}= \\
& 25-2=23)\} \\
& =\mathrm{F}\{(0,95)(1,23)\}
\end{aligned}
$$

Cara mencari $\mathrm{F}$ tabel: angka $1=$ pembilang angka $23=$ penyebut Ftabel $=4,28$ 
Ternyata Fhitung $>$ Ftabel, maka tolak $\mathrm{H}_{0}$ artinya signifikan

\section{Langkah Kedua belas:}

Membuat kesimpulan

Karena $F_{\text {hitung }}$ lebih besar dari $F_{\text {tabel }}$ atau 60,9> 4,28, maka tolak $\mathrm{H}_{\mathrm{o}}$ dan terima $\mathrm{H}_{\mathrm{a}}$. Dengan demikian terdapat pengaruh interaksi edukatif guru terhadap motivasi belajar siswa pada mata pelajaran Pendidikan Agama Islam di Sekolah Menengah Kejuruan Negeri 2 Tembilahan.

\section{Perhitungan Uji SPSS}

Selain menggunakan cara hitung manual di atas, penulis juga menggunakan perhitungan dengan program SPSS sebagai berikut:

Descriptive Statistics

\begin{tabular}{|l|c|c|c|}
\hline & $\mathrm{N}$ & Mean & Std. Deviation \\
\hline Interaksi & 25 & $\begin{array}{c}144,0 \\
8\end{array}$ & 11,228 \\
Edukatif & 25 & $\begin{array}{c}149,7 \\
6\end{array}$ & 12,888 \\
$\begin{array}{l}\text { Motivasi } \\
\text { Belajar }\end{array}$ & & & \\
\hline
\end{tabular}

Dari tabel di atas, dapat dilihat nilai rata-rata untuk variable interaksi edukatif (X) sebesar 144,08 sedangkan variabel motivasi Belajar (Y) sebesar 149,76. Adapun nilai simpangan baku dari variabel bebas (X) sebesar 11,228, sedangkan variabel terikat (Y) adalah 12,888 .

Berdasarkan tabel output SPSS "model summary" di atas, diketahui nilai koefesien determinasi atau R Square adalah sebesar 0,726. Nilai $R$ Square 0,726 ini berasal dari pengkuadratan nilai koefesien korelasi atau "R", yaitu $0,852 \times 0,852=0,726$. Besarnya angka koefesien determinasi (R Square) adalah 0,726 atau sama dengan $72,6 \%$. Angka tersebut mengandung arti bahwa variabel interaksi edukatif berpengaruh terhadap variabel motivasi belajar sebesar $72,6 \%$, sedangkan sisanya $(100 \%-72,6 \%=$ $27,4 \%$ ) dipengaruhi oleh variabel lain di luar persamaan regresi.

\begin{tabular}{|c|c|c|c|c|c|c|}
\hline \multicolumn{7}{|c|}{ ANOVA $^{a}$} \\
\hline \multicolumn{2}{|c|}{ Model } & $\begin{array}{l}\text { Sum of } \\
\text { Square }\end{array}$ & df & $\begin{array}{l}\text { Mean } \\
\text { Squar }\end{array}$ & $\mathrm{F}$ & Sig. \\
\hline \multirow{3}{*}{1} & $\begin{array}{c}\text { Regr } \\
\text { essio } \\
n\end{array}$ & $\begin{array}{c}2894,5 \\
75\end{array}$ & 1 & $\begin{array}{c}2894 \\
575\end{array}$ & \multirow[t]{3}{*}{$\begin{array}{l}60, \\
967\end{array}$} & \multirow[t]{3}{*}{, $000^{\mathrm{b}}$} \\
\hline & $\begin{array}{c}\text { Resid } \\
\text { ual }\end{array}$ & $\begin{array}{c}1091,9 \\
85\end{array}$ & 23 & $\begin{array}{c}47,47 \\
8\end{array}$ & & \\
\hline & Total & $\begin{array}{c}3986,5 \\
60\end{array}$ & 24 & & & \\
\hline
\end{tabular}

a. Dependent Variable: Motivasi Belajar

b. Predictors: (Constant), Interaksi Edukatif

Dari output tersebut diketahui bahwa nilai Fhitung $=60,967$ atau 60,9 sedangkan nilai Ftabel sebesar 4,28 yang artinya

Fhitung $>$ Ftabelartinyaterdapatpengaruh yang signifikanantara interaksi edukatif guru terhadap motivasi belajar siswa pada mata pelajaran Pendidikan Agama Islam di Sekolah Menengah Kejuruan Negeri 2 Tembilahan

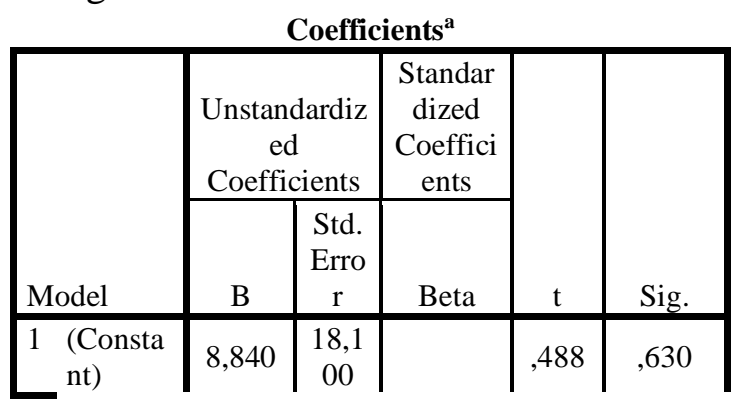

Model Summary

\begin{tabular}{|l|l|l|l|l|}
\hline Model & R & R Square & $\begin{array}{c}\text { Adjusted } \\
\text { R Square }\end{array}$ & $\begin{array}{c}\text { Std. Error } \\
\text { of the } \\
\text { Estimate }\end{array}$ \\
\hline 1 &, $852^{\mathrm{a}}$ &, 726 &, 714 & 6,890 \\
\hline
\end{tabular}

a. Predictors: (Constant), Interaksi Edukatif 
\begin{tabular}{l|l|l|l|c|c|}
\hline $\begin{array}{l}\text { Interaks } \\
\mathrm{i}\end{array}$ &, 978 &, 125 &, 852 & 7,80 &, 000 \\
$\begin{array}{l}\text { Edukati } \\
\mathrm{f}\end{array}$ & & & & 8 & \\
\hline
\end{tabular}

a. Dependent Variable: Motivasi Belajar

Diketahui nilai konstan (a) sebesar 8,840 , sedangkannilai interaksi edukatif (b/koefisien regresi) sebesar 0,978, sehingga persamaan regresinya dapat ditulis:

$$
\begin{aligned}
& Y=a+b X \\
& Y=8,840+0,978 X
\end{aligned}
$$

Persamaan tersebut dapat diterjemahkan:

Konstanta sebesar 8,840, mengandung arti bahwa nilai konsisten variabel motivasi belajar adalah sebesar 8,840 .

Koefisien regresi $\mathrm{X}$ sebesar 0,978 menyatakan bahwa setiap penambahan $1 \%$ nilai interaksi edukatif, maka nilai motivasi belajar bertambah sebesar 0,978. Koefisien regresi tersebut bernilai positif, sehingga dapat dikatakan bahwa arah pengaruh variabel $\mathrm{X}$ terhadap $\mathrm{Y}$ adalah positif.

Hasil penelitian yang berjudul "Pengaruh Interaksi Edukatif Guru Terhadap Motivasi Belajar Siswa pada Mata Pelajaran Pendidikan Agama Islam Di Sekolah Menengah Kejuruan Negeri 2 Tembilahan" diperoleh melalui data angket yang telah disebarkan pada siswa kelas XI Jurusan TKJ yang berjumlah 25 orang. Selanjutnya, data tersebut dianalisis menggunakan uji regresi sederhana untuk mengetahui ada tidaknya pengaruh interaksi edukatif guru terhadap motivasi belajar siswa pada mata pelajaran Pendidikan Agama Islam.
Sedangkan, perhitungan dengan menggunakan analisis regresi sederhana pada data angket diperoleh Fhitung sebesar 60,9 sedangkan Ftabel pada taraf signifikan 5\% sebesar 4,28 dengan demikian Fhitung > Ftabel yang berarti Ha diterima dan Ho ditolak, artinya terdapat pengaruh yang signifikan antara interaksi edukatif guru terhadap motivasi belajar siswa.

\section{KESIMPULAN}

Berdasarkan hasil penelitian yang telah penulis lakukan di Sekolah Menengah Kejuruan Negeri 2 Tembilahan melalui teknik pengumpulan data berupa angket maka dapat disimpulkan bahwa:

1. Interaksi edukatif guru di Sekolah Menengah Kejuruan negeri 2 Tembilahan berada pada kategori sedang yaitu sebanyak 15 siswa (62\%) dari sampel yang berjumlah 25 siswa.

2. Motivasi belajar siswa di Sekolah Menengah Kejuruan negeri 2 Tembilahan berada pada kategori sedang yaitu sebanyak 13 siswa (52\%) dari sampel yang berjumlah 25 siswa.

3. Terdapat pengaruh yang signifikan antara interaksi edukatif guru terhadap motivasi belajar siswa pada mata pelajaran Pendidikan Agama Islam di Sekolah Menengah Kejuruan Negeri 2 Tembilahan berdasarkan hipotesis $\mathrm{H}_{\mathrm{a}}$ terima dan $\mathrm{H}_{0}$ ditolak dengan ketentuan hipotesis $F_{\text {hitung }}$ $60,9>\mathrm{F}_{\text {tabel }} 4,28$. 


\section{REFERENSI}

Agus Purwanto, Erwan, Dyah Ratih Sulistyastuti. 2007. Metode Penelitian Kuantitatif Untuk Administrasi Publik dan Masalahmasalah Sosial. Yogyakarta: Gava Media.

Aqib, Zainal, Elham Rahmanto. 2007. Membangun Profesionalisme Guru dan Pengawas Sekolah. Bandung: Yrama Widya.

Arifin, Zainal. 2012. Penelitian Pendidikan: Metode dan Paradigma Baru. Bandung: remaja Rosdakarya.

Bahri Djamrah, Syaiful. 2000. Guru dan Anak Didik dalam Interaksi Edukatif. Jakarta: Rineka Cipta.

Bungin, Burhan. 2010. Metodologi Penelitian Kuantitatif. Jakarta: Kencana Prenada Media Group.

B. Uno, Hamzah. 2011. Teori Motivasi dan Pengukurannya. Jakarta: Bumi Aksara.

Hadis, Abdul, Nurhayati. 2014. Psikologi dalam Pendidikan. Bandung: Alfabeta.

Hamalik, Oemar. 2005. Psikologi Belajar dan Mengajar. Bandung: Sinar Baru Algensindo.

Khodijah, Nyanyu. 2016. Psikologi Pendidikan. Jakarta: Rajawali Press.

Mahfan. 2005. Kamus Besar Bahasa Indonesia. Jakarta: Sandro.

M. Musfiqon. 2012. Metodologi Penelitian Pendidikan. Jakarta: Prestasi Pustakarya.

Noor, Juliansyah. 2012. Metodologi Penelitian: Skripsi, Tesis, Disertasi, dan Karya Ilmiah. Jakarta: Kencana Prenada Media Group.

Riduwan. 2011. Belajar Mudah Penelitian: Untuk Guru, Karyawan dan Peneliti Pemula. Bandung: Alfabeta.

Ridwan. 2011. Metode dan Teknik Menyusun Tesis. Bandung: Alfabeta.

Sagala, Syaiful. 2006. Konsep dan Pembelajaran. Bandung: Alfabeta.
Sanjaya, Wina. 2008. Kurikulum dan Pembelajaran: Teori dan Praktik Pengembangan Kurikulum Tingkat Satuan Pendidikan (KTSP). Jakarta: Kencana Prenada Media Group.

Sardiman A.M. 2016. Interaksi dan Motivasi Belajar Mengajar. Jakarta: Rajawali Press.

Sugiyono. 2016. Metode Penelitian Kuantitatif, Kualitatif dan $R \& D$. Bandung: Alfabeta.

Sukardi. 2003. Metodologi Penelitian Pendidikan: Kompetensi dan Praktiknya. Jakarta: Bumi Aksara.

Surachim, Ahim. 2016. Efektivitas Pembelajaran: Pola Pendidikan Sistem Ganda. Bandung: Alfabeta.

Syarif Sumantri, Mohamad. 2015. Strategi Pembelajaran: Teori dan Praktik di Tingkat Pendidikan Dasar. Jakarta: Rajawali Press.

Wahab, Rohmalina. 2016. Psikologi belajar. Jakarta: Rajawali Press.

Widodo. 2004. Cerdik Menyusun Proposal Penelitian. Jakarta: Yayasan Kelompok.

Yulianti Zakiyah, Qiqi, A. Rusdiana. 2014. Pendidikan Nilai: Kajian Teori dan Praktik di Sekolah. Bandung: Pustaka Setia. 